\title{
Application of Remote Sensing Methods to Monitor Coastal Zones
}

\author{
Luis Pedro Almeida ${ }^{1,2, *}$ and Rafael Almar ${ }^{2}$ (D) \\ 1 Instituto de Oceanografia, Universidade Federal do Rio Grande (FURG), Rio Grande 96203-900, Brazil \\ 2 Laboratoire d'Etudes en Géophysique et Océanographie Spatiales (LEGOS), Université de \\ Toulouse/CNRS/CNES/IRD, 31400 Toulouse, France; rafael.almar@ird.fr \\ * Correspondence: lpalmeida@furg.br
}

Received: 27 May 2020; Accepted: 27 May 2020; Published: 29 May 2020

Keywords: unnamed aerial vehicles; LiDAR; video imagery; multispectral satellite imagery; radar; nearshore topography; nearshore bathymetry; landslides; seagrass

In this Special Issue "Application of Remote Sensing Methods to Monitor Coastal Zones" nine original research papers were published, with topics covering a wide range of ranging of remote sensing applications including coastal topography, bathymetry, land cover, and nearshore hydrodynamics. With the increasing number of studies showing that climate changes and particularly sea-level rise will radically redefine the physical condition of the nearshore zone of the 21st century [1,2], it is crucial to increase the efforts to monitor this area. Sandy beaches and dunes are a natural buffer in the first line of defense against erosion processes. In this Special Issue, three publications were dedicated to innovative methodologies to measure 3D beach/dune topography. The paper published by [3] presents a novel low-cost methodology that uses a GoPro-equipped DJI Phantom 2 quadcopter to routinely survey upper beach and coastal dune morphological changes. This methodology can be replicated elsewhere, and high-resolution $(0.1 \mathrm{~m})$ and accurate Digital Surface Model (DSM) can be inferred at high frequency (e.g., before and after a storm). The publication of [4] presents a detailed comparison between an extensive in-situ RTK-GPS survey performed simultaneously with UAV image acquisition. The comparison between the two methods highlights how the complexity of the surveyed surfaces (including beach, dune, road, and walkways) affects the accuracy of the generated 3D digital surface model (DSM). A distinct approach is presented by [5] who details the algorithms implemented on observations from a shore-based 3D terrestrial LiDAR system to automatically retrieve 3D beach/dune topography and wave transformation/runup, simultaneously. This system is capable of recording continuous, high frequency (hourly), and high-resolution datasets, which provide opportunities for analyses of coastal morphodynamic processes at a wide range of temporal and spatial scales. The publication presented by [6] demonstrates how a short-term deployment of a 2D LiDAR can provide useful information to understand wave runup processes on a steep sandy beach with a low tide terrace. Aspects such as the lack of dependence between offshore wave characteristics and runup during low tide conditions or berm erosion and formation can be further investigated with this type of instrument, which singularly allows simultaneous beach morphology and hydrodynamics monitoring.

Measurements of nearshore bathymetry are considerably more challenging to obtain than beach/dune topography, although crucial for a comprehensive understanding of the sediment exchanges in the nearshore system. The publication by [7] presents an error evaluation of the depth inversion based on wave kinematics detection from video imagery. In addition to the novel method to estimate errors in bathymetric estimations, this paper provides a demonstration of the potential of this methodology by presenting a three-year time-series of bathymetry estimations at a tropical sandy beach with low tide terrace under tropical cyclone (typhoons) and monsoon forcing. The paper published by [8] 
presents a video-based methodology that allows the automatic identification of shoaling, surf, and swash zones on coastal video images. This method allows a detailed description of the spatial and temporal variation of wave transformation domains in the nearshore zone and can possibly improve existing algorithms for wave breaking height and celerity estimations.

In addition to beach/dune erosion, landslides are one of the most frequent and serious geological disasters that can take place in the nearshore zone. The paper published by [9] shows a novel methodological approach to measure real-time dynamic deformation of rocky cliffs using high-precision ground-based real aperture radar (GB-RAR). Land displacements and potential landslides are monitored continuously to realize the real-time diagnosis and early warning systems.

In addition to the physical condition of the nearshore zone, in this Special Issue two publications present distinct methods to map vegetation in the coastal region. The paper published by [10] presents a low-cost smartphone-based image classification for Sargassum algae detection and monitoring. The method proves to have accuracy in the range between $75 \%$ and $96 \%$ and to be effective in a warning system. Using high spatial resolution ( $2 \mathrm{~m}$ ) WorldView-2 satellite multispectral imagery, [11] presents an object-based image classification method to identify seagrass meadow distributions with $94 \%$ accuracy. This study concludes that WorldView-2 satellite imagery is a suitable data source for seagrass distribution mapping over large areas.

Luis Pedro Almeida

Rafael Almar

Guest Editors of "Application of Remote Sensing Methods to Monitor Coastal Zones"

Conflicts of Interest: The authors declare no conflict of interest.

\section{References}

1. Taherkhani, M.; Vitousek, S.; Barnard, P.L.; Frazer, N.; Anderson, T.R.; Fletcher, C.H. Sea-level rise exponentially increases coastal flood frequency. Sci. Rep. 2020, 10, 6466. [CrossRef] [PubMed]

2. Vousdoukas, M.I.; Ranasinghe, R.; Mentaschi, L.; Plomaritis, T.A.; Athanasiou, P.; Luijendijk, A.; Feyen, L. Sandy coastlines under threat of erosion. Nat. Clim. Chang. 2020, 10, 260-263. [CrossRef]

3. Laporte-Fauret, Q.; Marieu, V.; Castelle, B.; Michalet, R.; Bujan, S.; Rosebery, D. Low-Cost UAV for High-Resolution and Large-Scale Coastal Dune Change Monitoring Using Photogrammetry. J. Mar. Sci. Eng. 2019, 7, 63.

4. Bañón, L.; Pagán, J.I.; López, I.; Banon, C.; Aragonés, L. Validating UAS-Based Photogrammetry with Traditional Topographic Methods for Surveying Dune Ecosystems in the Spanish Mediterranean Coast. J. Mar. Sci. Eng. 2019, 7, 297. [CrossRef]

5. O'Dea, A.; Brodie, K.L.; Hartzell, P. Continuous Coastal Monitoring with an Automated Terrestrial Lidar Scanner. J. Mar. Sci. Eng. 2019, 7, 37. [CrossRef]

6. Almeida, L.P.; Almar, R.; Blenkinsopp, C.; Senechal, N.; Bergsma, E.; Floc'h, F.; Caulet, C.; Biausque, M.; Marchesiello, P.; Grandjean, P.; et al. Lidar Observations of the Swash Zone of a Low-Tide Terraced Tropical Beach under Variable Wave Conditions: The Nha Trang (Vietnam) COASTVAR Experiment. J. Mar. Sci. Eng. 2020, 8, 302. [CrossRef]

7. Thuan, D.H.; Almar, R.; Marchesiello, P.; Viet, N.T. Video Sensing of Nearshore Bathymetry Evolution with Error Estimate. J. Mar. Sci. Eng. 2019, 7, 233.

8. Andriolo, U. Nearshore Wave Transformation Domains from Video Imagery. J. Mar. Sci. Eng. 2019, 7, 186.

9. Ma, D.; Li, Y.; Cai, J.; Li, B.; Liu, Y.; Chen, X. Real-Time Diagnosis of Island Landslides Based on GB-RAR. J. Mar. Sci. Eng. 2020, 8, 192. [CrossRef]

10. Valentini, N.; Balouin, Y. Assessment of a Smartphone-Based Camera System for Coastal Image Segmentation and Sargassum monitoring. J. Mar. Sci. Eng. 2020, 8, 23.

11. Su, L.; Huang, Y. Seagrass Resource Assessment Using WorldView-2 Imagery in the Redfish Bay, Texas. J. Mar. Sci. Eng. 2019, 7, 98.

(C) 2020 by the authors. Licensee MDPI, Basel, Switzerland. This article is an open access article distributed under the terms and conditions of the Creative Commons Attribution (CC BY) license (http://creativecommons.org/licenses/by/4.0/). 